Jefreeys, H., 1929. The Earth, Cambridge, p. 79.

KUENEN, Ph. H., 1947. Geol. Mag., 84, p. 57.

SANDELL, E. B., and GoldICH, S. S., 1943. Journ. Geol., 51, pp. 99 and 167.

Grant INSTITUTE OF GeOLOGY,

ARTHUR Holmes.

UNIVERSITY OF EDINBURGH.

11 th February, 1947.

SIR,--My criticism of Holmes's paper, although evidently unfounded, has induced him to clarify a point that I know had troubled others besides myself, in advance of his detailed treatment. In spite of being a wiser man, I need therefore be no sadder.

Geologisch InstituUt,

RIJKS-UNIVERSITEIT,

TE GRONINGEN.

24th February, 1947.

Ph. H. Kuenen.

\title{
CHILLED AND "BAKED" EDGES AS CRITERIA OF RELATIVE AGE
}

SIRS,-As an old campaigner, who is for ever grateful for the assistance he has received from corrections by fellow-workers, may I say how much I enjoyed the January-February number of the Geological Magazine? There are at least two divergent schools of petrology at work in the British Isles, and the more we get together, so as to tackle simultaneously identical problems, the quicker we shall arrive at satisfactory agreement. The principle of a reserved area is abhorrent to my consciousness of the sanctity of Science.

The title adopted for this correspondence is attractive. Scottish geologists, including many who are Scottish by choice rather than birth, have paid special attention to the lessons to be learned from chilled edges. The earliest case on record seems to be that of James Hall, who in 1798 announced deductions derived from a study of chilled edges of dykes at Monte Somma. Later, the cult of chilled edges was developed by masters such as Clough and Peach. Harker, however, never fully appreciated their value. This is well seen in a remark he once made in combating criticism $I$ had advanced of his interpretation of the Sgurr of Eigg : "For some of my friends on the Geological Survey this matter of chilled edges seems to have become, in these latter days, a kind of cheap and infallible touch-stone" (G.M., 1914, p. 307). Sallies such as this I have always greatly enjoyed as enlivening debate and at the same time recording opinion.

The letter in your last issue, upon which I wish to comment, is by D. B. McIntyre and Doris L. Reynolds (G.M., 1947, p. 61). It begins 
by quoting a statement from a previous letter by J. E. Richey, F. H. Stewart, and L. R. Wager (G.M., 1946, p. 293). These three authors had found a marscoite at certain localities, chilled against a granophyre, and had drawn the natural conclusion that the particular marscoite is later than the particular granophyre. With this, McIntyre and Reynolds contrast Harker's well-known claim that the marscoite is earlier than the granophyre. Later in the letter McIntyre confirms some part of the phenomena relied upon by Harker, and points to a granophyre invading a marscoite. It seems probable to me that there are either two granophyres or two marscoites, or perhaps a succession of granophyres and marscoites. At the same time, Mclntyre hints at another possible solution. If this is developed in detail, and if by chance it is not found acceptable by Richey, Stewart, and Wager, it would seem that the stage will be set for a profitable discussion.

McIntyre and Reynolds, in their letter, deal concurrently with the Tertiary centre at Slieve Gullion. Reynolds here interprets the margin of a particular dolerite in contact with a granophyre as showing baking following upon chilling. Apparently the same margin has been interpreted by Richey as showing baking without antecedent chilling. I have examined a slice illustrating the difference of opinion, and certainly adopt Reynolds's interpretation. I admit that I may be wrong, and am anxious to consider contrary evidence. Meanwhile I seem to be one of many who are convinced that Reynolds has done good service in returning the dolerites and gabbros of Slieve Gullion to the Tertiary assemblage $(1937,1941)$, and still better in discovering remarkable metasomatic alteration of adjoining Caledonian granodiorite. The alteration, as she has pointed out, has proceeded preferentially along the external margins of glomero-aggregates of quartz. It certainly seems to me to some extent metasomatic. For instance, a slice $I$ have been shown contains rims which, so far as I can see, locally consist of pure orthoclase developed at the expense of the quartz (and possibly. of some adjoining oligoclase). I admit that I am not convinced by Reynolds's argument for solid diffusion (Q.J.G.S., 1941, p. 15), if this means more than that the quartz areas have tended to fill with new material, much as the water areas of vesicles do when they start to become amygdales. Appearances suggest to me transit of a mobile magmatic solution (emanation seems a good name) along cracks. It is well known that granite does crack when quickly heated at ordinary pressures, and this is ascribed to differential expansion of quartz and felspar. Silica has peculiar propensities : up to $573^{\circ}$ a-quartz expands at increasing rate ; at $573^{\circ}$ it expands suddenly to yield $\beta$-quartz; on further heating $\beta$-quartz contracts extremely slowly, until at above $870^{\circ} \mathrm{C}$, in the presence of a flux, it begins to pass with marked expansion to tridymite. 
May I say that, though I have from time to time described emanation phenomena (Colonsay Mem., 1911, p. 29 ; Glen Coe Mem., 1915, pp. 112, 164 ; Mull Mem., 1924, pp. 167, 319), I have nowhere seen a more hopeful field of research in this respect than has been opened by Reynolds's disceveries at Slieve Gullion.

19 Greenhill Gardens,

E. B. BAILEY.

\section{EDINBURGH.}

18 th February, 1947.

\section{AGE RELATIONS OF CERTAIN GRANITES IN SKYE}

SIR,-In their letter in the Geological Magazine for JanuaryFebruary, 1947, Dr. Doris Reynolds and Mr. McIntyre discuss inter alia the relative age of certain rocks in Skye. Their opinion in this particular case seems to be summarized in a statement at the end of the sixth paragraph of their letter which reads as follows : " the Allt Daraich-Sron a'Bhealain sheet of marscoite is seen both to be chilled against the granophyre and to occur as inclusions within it." This statement assumes that the granophyre against which the marscoite is chilled is the same as the granophyre which contains the marscoite inclusions (Harker's spotted granophyre). Dr. Reynolds and Mr. McIntyre give no evidence to justify this assumption. In our view two granophyres of different ages are involved. One line of evidence on which we rely is the chilled contact to which we originally drew attention but it appears that for others such evidence has a different meaning.

The particular problem of the age of these Skye rocks cannot be discussed satisfactorily within the limits of a letter in this journal. We shall present a map and petrological account in due course.

J. E. RICHEY.

F. H. Stewart.

24th February, 1947.

L. R. WAGER. 